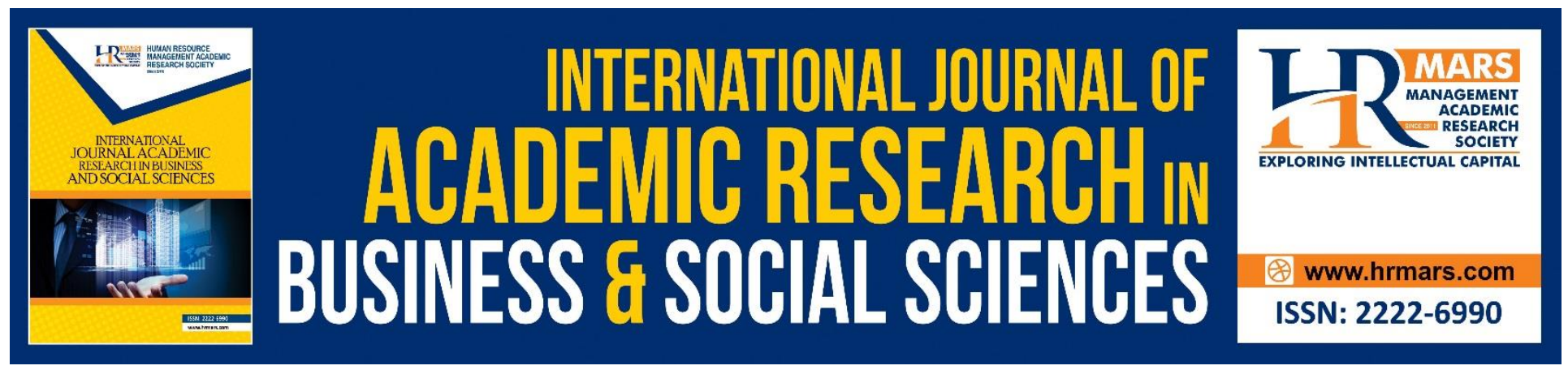

\title{
Relationship of Personality with the Self Efficacy of Islamic Education Teachers in the Districts Of Besut, Setiu, and Kuala Nerus of Terengganu State
}

Nor Asmawati Ismail, Najihah Abd Wahid

To Link this Article: http://dx.doi.org/10.6007/IJARBSS/v8-i11/4963

DOI: $10.6007 /$ IJARBSS/v8-i11/4963

Received: 27 Sept 2018, Revised: 13 Oct 2018, Accepted: 16 Nov 2018

Published Online: 03 Dec 2018

In-Text Citation: (Ismail \& Wahid, 2018)

To Cite this Article: Ismail, N. A., \& Wahid, N. A. (2018). Relationship of Personality with the Self Efficacy of Islamic Education Teachers in the Districts Of Besut, Setiu, and Kuala Nerus of Terengganu State.

International Journal of Academic Research in Business and Social Sciences, 8(11), 866-876.

Copyright: (c) 2018 The Author(s)

Published by Human Resource Management Academic Research Society (www.hrmars.com)

This article is published under the Creative Commons Attribution (CC BY 4.0) license. Anyone may reproduce, distribute, translate and create derivative works of this article (for both commercial and non-commercial purposes), subject to full attribution to the original publication and authors. The full terms of this license may be seen at: http://creativecommons.org/licences/by/4.0/legalcode

Vol. 8, No. 11, 2018, Pg. 866 - 876

http://hrmars.com/index.php/pages/detail/IJARBSS

JOURNAL HOMEPAGE

Full Terms \& Conditions of access and use can be found at http://hrmars.com/index.php/pages/detail/publication-ethics 


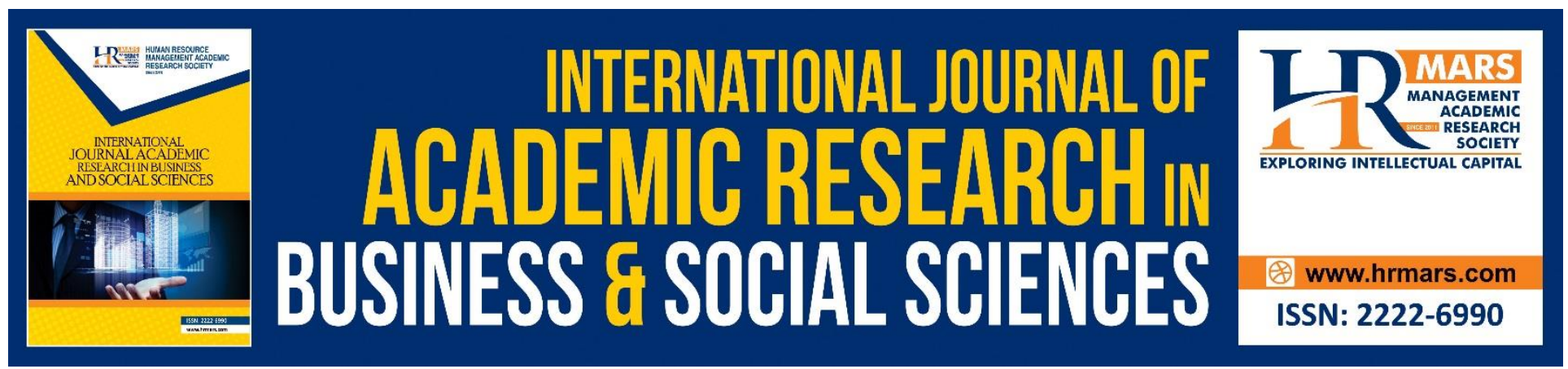

\title{
Relationship of Personality with the Self Efficacy of Islamic Education Teachers in the Districts Of Besut, Setiu, and Kuala Nerus of Terengganu State
}

\author{
Nor Asmawati Ismail ${ }^{1}$, Najihah Abd Wahid ${ }^{2}$ \\ ${ }^{1}$ Faculty of Islamic Contemporary Study, ${ }^{2}$ Research Institute for Islamic Product and Malay \\ Civilisation, Universiti Sultan Zainal Abidin \\ E-mail: asmawati730122@gmail.com, anajihah@unisza.edu.my
}

\begin{abstract}
This research paper aims to identify the relationship of personality with the self-efficacy of Islamic Education Teachers (GPI) in primary schools in three districts on Terengganu state. There were 33 GPIs in Besut, Setiu, and Kuala Nerus being selected randomly as the research respondents. This research was conducted through the quantitative approach by using the instrument adapted from the Big Five Inventory Scale by John and Srivastava (1999) and Teacher Sense of Efficacy Scale by Tschannen-Moran \& Hoy (2001). The data that involves score means and the correlation was analysed by the Statistical Packages for Social Sciences (SPSS) software, version 22.0. The descriptive analysis findings indicate that the personality value $(M=3.68)$ and self-efficacy $(M=3.87)$ are rated on the medium-high level. Meanwhile, the agreeableness dimension stated as the most dominant personality with the record of the highest score $(M=4.32)$, followed by the dimension of conscientiousness $(M=3.84)$, extraversion $(M=3.78)$, openness $(M=3.53)$ and neuroticism $(M=2.99)$. the finding also indicates the highest self-efficacy level belongs to the dimension of class management $(M=3.91)$, followed by the student's management $(M=3.90)$ and teaching strategy $(M=3.79)$. The result from the Pearson correlation indicates the presence of a significant relationship between the dimension of openness $\left(r=0.616^{* *}\right)$, conscientiousness $\left(r-0.605^{* *}\right)$ and agreeableness $\left(r=0.364^{*}\right)$ with self-efficacy. However, the dimensions of extraversion $(r=0.068)$ and neuroticism ( $r=-0.171$ ) are showing the absence of significant correlation towards the self-efficacy. Henceforth, this conducted research able to become as the foundation towards understanding the personality trait in order to elevate the self-efficacy amongst GPI.
\end{abstract}

Keywords: Personality, self-efficacy, Islamic Education Teachers 


\section{INTRODUCTION}

In referring to the former report of Malaysia Education Blueprint 2013-2025, Malaysia Ministry of Education (MOE) is continuously committed to remain the established policy, which is to strengthen the teaching profession in Malaysia in order to make it interesting, giving satisfaction and prestigious value. A skilful and spirited teacher able to be produced if that respective figure possesses the high self-efficacy and the characteristics that are required to be known as a teacher.

\section{LITERATURE REVIEW RELATED TO SELF-EFFICACY AND PERSONALITY}

The advancement of the education system of a country depends on the quality of a teacher. Teachers are regarded as the major asset towards producing the first class minded human capitals. Hence, the high self-efficacy teachers are the vital element towards actualizing the wish of MOE in producing the educated generation. This is supported with the opinion of Khairul Anuar (2012) that stated the career in the teaching field is one of the professions that have its own role towards in determining the future generation.

The self-efficacy of teachers is not new and foreign terminology amongst the international researchers, however, this element is still considered as a new issue in Malaysia's education world. Furthermore, the term of self-efficacy itself is still not fully comprehended by certain teachers (Masitah Azizi, Ahmad, Bahaman, Ramli, Noriati \& Mohamed, 2011). Even though the self-efficacy of teachers is not receiving high exposure in the world of education, it does not mean that this issue is never existing. This statement is seconded by the research finding from Ishak (2011) that able to identify the stage of self-efficacy amongst teachers were in the average value.

Moreover, the self-efficacy and personality also considered as an important factor and giving their great influence in determining the ability and competency of teachers during conducting the duty and responsibility as educators (Pandey and Kavita, 2015; Hazalizah \& Nor Haslizah, 2014, Godana, Snezana \& Mila, 2013). As aforementioned, every human being possesses unique, own and different personality from other people. The distinction is possibly happened due to the genetic factor and the surrounding atmosphere (Maarof and Haslinda, 2004), and the biological characteristics that respond as the personality determinant that showing the difference from the perspective of thought and the action behaviour (Baharom \& Iliyas. 2011)

Thus, this research aims to observe the level and relationship between personality with self-efficacy of Islamic Education Teachers in the districts of Besut, Setiu and Kuala Nerus.

\section{PERSONALITY AND SELF-EFFICACY ACCORDING TO SCHOLARS}

\section{Personality}

The term of personality derived from the Latin word of persona literally meaning 'mask'. It is formerly referred to a mask that is used by the actors in certain dramas or theatres. In the meantime, it is trying to explain the word persona or personality means the outer appearance and characteristic that can be seen and observed by others (Schultz \& Schultz, 2009). 
The fourth edition of Dewan Bahasa Dictionary defines the personality as self-quality or character. Schultz \& Schultz (2009) defined personality as an inner and outer characteristic that is constant and unique for each individual. Those characteristics able to influence an individual in different situations. Personality is a psychology quality that stimuli the constant and unique feeling pattern, thought and behaviour that is beyond the time and situation (Pervin \& Cervone, 2010). VandenBos (2007) in APA Dictionary Psychology defines personality as the configuration of characteristics and behaviour that influence the unique adjustment in life, including the major traits, motivation, interest and selfconcept. From the aforementioned definitions, Hazalizah (2011) postulated that many of the researchers emphasize two major definitions of personality, which are unique and constant. There is no specific definition being mutually agreed and concurred by the personality scientists owing to each type of personality has a different definition. It is discussed from the perspective and vision of certain theorists of personality in defining it (Pervin \& Cervone, 2010; Schultz \& Schultz, 2009).

However, this research opted the definition proposed by Ryckman (20123) that stated the personality is a dynamic and organised characteristic inside an individual which uniquely influence the cognitive, motivation and behaviour in many conditions and situations. It is a scientific analysis of the differences between individuals that are related to the aspect of why and how the human responds towards the surrounding changing.

There are five characteristics of personality that were proposed; extraversion, neuroticism, agreeableness, openness and conscientiousness. The first characteristic is extraversion which is featured as active, high confidence level, love to associate with others, enjoy giving opinion and idea, talkative, optimistic and positive (Costa and McCrae, 1992). Usually, this kind of people receives high payment, satisfy with their work and have chances to upgrade the career prestation.

The second characteristic is neuroticism, and usually in contrary with the emotional balance such as inappropriate behaviour, quick-tempered, easily losing control of patience, always nervous, stress and always anxious. Usually, they always experience the negative incidents in their life. Hence, the neurotics are not content and please along of their career experiences (John and Srivastava, 1999).

The third characteristic, agreeableness refers to the act of respecting others, practising courtesy, being easily trusted, always cooperate, easily forgiving others, effortlessly liking others, tolerate, kind-hearted and flexible (Barrick and Mount, 1991).

The fourth characteristic is openness which described as like to imagine, able to listen and accept the opinions of other people, and in the same time, they have their own original idea, like to honestly confess and have nothing to conceal, intuitive, able to think on something, honest and not possess any hidden agenda, open-minded and artistic (Barrick \& Mount, 1991).

The fifth characteristic is conscientiousness; always doing the work carefully, perfect, meticulous and thorough, having a concrete stance of the idea, motivated in actualizing the clear and noticeable 
INTERNATIONAL JOURNAL OF ACADEMIC RESEARCH IN BUSINESS AND SOCIAL SCIENCES

Vol. 8, No. 11, Nov, 2018, E-ISSN: 2222-6990 C 2018 HRMARS

objective, responsible and smart in management. These characteristics usually related to the field of education and motivation (Barrick \& Mount, 1991).

\section{Self-Efficacy}

Self-efficacy refers scientifically on the possible extent that an individual opts to be certain on his or her ability in achieving certain aims. It is an evaluation of the capability to organized and completing the required series of performance in accomplishing the focussed aim (Bandura, 1982).

The teacher's self-efficacy is a trust that is developed related to the capability of teachers in motivating the students to learn and get the excellent achievement, including amongst the lessmotivated and problematic ones. The research conducted by Dibapile (2012) succeeds in proving that self-efficacy teachers are the heartbeat centre in the excellence of students. However, teacher's selfefficacy is a vast element that is generally combining the teacher's trust and the self-ability of an individual.

Tschannen-Moran and Hoy (2001) defined the teacher's self-efficacy as a confidence that is possessed by a teacher towards his or her ability in teaching and motivating the students without concerning on their competency and family backgrounds. There are three factors proposed by Tschannen-Moran and Hoy (2001) in categorizing teacher's self-efficacy; efficacy on the teaching strategy, efficacy on classroom management and efficacy on the students' involvements.

In short, teacher's self-efficacy in this research paper refers to the belief or confidence of a teacher related to his or her ability in organizing and performing series of actions that are required in completing the tasks of teaching, specifically in school. Self-efficacy of teachers also referring to the certainty of teachers with their knowledge, skills and ability towards achieving certain objectives.

\section{METHODOLOGY}

This research is a qualitative study that utilizing the approach of a descriptive survey. There were 33 of GPI respondents from the districts of Besut, Setiu and Kuala Nerus, Terengganu. The opted instruments in this section is Big Five Inventory Scale (BFI); a personality characteristic adapted by John \& Srivastava (1990). This instrument has five dimensions which are extraversion, agreeableness, openness and conscientiousness. The whole total items are 44 and each of the items has eight to ten items. These 44 items of $\mathrm{BFI}$ are easily comprehended to evaluate the prototypical characteristic that defines each of those personality factors (Fatimahwati \& Ling, 2016). 
INTERNATIONAL JOURNAL OF ACADEMIC RESEARCH IN BUSINESS AND SOCIAL SCIENCES

Vol. 8, No. 11, Nov, 2018, E-ISSN: 2222-6990 @ 2018 HRMARS

Table 1: Personality Characteristic Dimensions dan Item's Number

\begin{tabular}{|c|c|c|c|c|}
\hline Dimension & Positive Item Num. & Negative Item Num. & Total & \\
\hline 1. Extraversion & $1,11,16,26,36$ & $6,21,31$ & & 8 \\
\hline 2. Neuroticism & $4,14,19,29,39$ & $9,24,34$ & & 8 \\
\hline 3. Agreeableness & $7,17,22,32,42$ & $2,12,27,37$ & 9 & \\
\hline 4. Openness & $5,10,15,20,25,30,40,44$ & 35,41 & 10 & \\
\hline 5. Conscientiousness & $3,13,28,33,38$ & $8,18,23,43$ & & 9 \\
\hline Total & 29 items & 16 items & & 44 \\
\hline
\end{tabular}

This five-scale survey is using the value started from ' 1 ' as 'never happen' until ' 5 ' as 'frequently happen'.

Meanwhile, the survey that was being used to test the teacher' self-efficacy is Teacher Sense of Efficacy Scale (TSES) instrument. It was developed by Tschannen-Moran \& Woolffolk-Hoy (2001). The questionnaire contains three dimensions which are teaching strategy, class management and student involvement. Teaching strategy is a teacher's consideration on the self-ability to manage teaching activity hence the student could understand the content of the lesson and achieve the teaching objective. Meanwhile, class management is a teacher commitment to control the class and provide a conducive teaching and learning environment. Student involvement is a teacher's effort and determination in motivating the students to involve themselves in the teaching activities are being conducted (Khalid, Zurida, Shukri \& Ahmad Tajuddin, 2009). These dimensions respectively having four items. Table 2 indicates the dimensions and the number of related items.

Table 2: Dimension and Self-Efficacy Item

\begin{tabular}{ll}
\hline Dimension & Item \\
\hline Student Involvement & $2,3,4$ and 11 \\
Teaching Strategy & $5,9,10$ and 12 \\
Class Management & $1,6,7$ and 8 \\
\hline
\end{tabular}

This questionnaire is using five-point scale started with ' 1 ' as 'strongly unable' which referring to the lowest self-efficacy until ' 5 ' as 'strongly able' which referring to highest self-efficacy. This instrument does not have any negative statement item.

Generally, the study employed two instruments which are personality and self-efficacy instrument. These instruments will be analysed using SPSS version 22.0 to identify the level and relationship of personality and self-efficacy. Table 3 indicates the summary of the instruments in this study. 
INTERNATIONAL JOURNAL OF ACADEMIC RESEARCH IN BUSINESS AND SOCIAL SCIENCES Vol. 8, No. 11, Nov, 2018, E-ISSN: 2222-6990 @ 2018 HRMARS

Table 3: Summary of the Instrument and the Total Item Used in the Study

\begin{tabular}{cccc}
\hline Part & Study Variables & Total Item & Source \\
\hline A & Demography & 4 & \\
B & Personality & 44 & John and Srivastava (1999) \\
C & Self-Efficacy & 12 & Tschannen-Moran and Hoy \\
& & & (2001) \\
\hline Total Item & & 62 & \\
\hline
\end{tabular}

\section{RESULTS AND DISCUSSIONS}

\section{Level of Personality Trait of Islamic Education Teacher Analysis}

Table 4 shows the mean value and standard deviation of each personality trait dimension of GPI. There are five personality traits measured which are Extraversion, Neuroticism, Agreeableness, Openness, dan Conscientiousness. The result of the study indicates that Agreeableness dimension recorded the highest mean value $(M=4.23, S D=0.42)$. Meanwhile, there are three dimensions that stated medium-high mean value which are Conscientiousness $(M=3.84, S D=0.38)$, Extraversion $(M=$ $3.78, \mathrm{SD}=0.36)$, Openness $(\mathrm{M}=3.53, \mathrm{SD}=0.40)$, and Neuroticism dimension stated medium-low mean $(\mathrm{M}=2.99, \mathrm{SD}=0.43)$.

Table 4: Mean Value and Standard Deviation of Personality Trait of GPI

\begin{tabular}{cccc}
\hline Personality Trait & Mean & Standard Deviation & Level \\
\hline Extraversion & 3.78 & 0.36 & Medium-High \\
Neuroticism & 2.99 & 0.43 & Medium-Low \\
Agreeableness & 4.23 & 0.42 & High \\
Openness & 3.53 & 0.40 & Medium-High \\
Conscientiousness & 3.84 & 0.38 & Medium-High \\
\hline
\end{tabular}

In conclusion, GPI in the district of Besut, Setiu and Kuala Nerus is having personality traits that are appropriate to the teaching role field. The result is in line with the study conducted by Feshbach, Weiner and Bohart (1996), Heinstrom (2003), Kahirol, Nurhasliza, Nor Lisa, Badaruddin and Mohamad Zaid (2008), Asrul Azmin (2010) and Zulelawati and Yusni (2015) which found that all five personality traits are having a relationship with the cognitive, affective and behaviour of a teacher.

\section{Level of Self-Efficacy of Islamic Education Teacher Analysis}

Table 5 indicates the mean value and standard deviation for GPI's self-efficacy. There are three dimensions that were being valued; management of student, teaching strategy and class management. The findings indicate that all three mean is in the medium-high level. The highest dimension is Class Management $(M=3.91, S D=0.48)$, followed by Student Management $(M=3.90$, $S D=0.39)$ and Teaching Strategy $(M=3.79 . S D=0.58)$. 
INTERNATIONAL JOURNAL OF ACADEMIC RESEARCH IN BUSINESS AND SOCIAL SCIENCES Vol. 8, No. 11, Nov, 2018, E-ISSN: 2222-6990 @ 2018 HRMARS

Table 5: Mean value and Standard Deviation for Self-Efficacy of GPI

\begin{tabular}{cccc}
\hline Self-Eficacy & Mean & Standard Deviation & Level \\
\hline Student & 3.90 & 0.39 & Medium-High \\
Management & & & \\
Teaching Strategy & 3.79 & 0.58 & Medium-High \\
Class Management & 3.91 & 0.48 & Medium-High \\
\hline
\end{tabular}

Based on the finding above, it can be concluded that self-efficacy of GPI is on the level of mediumhigh. This result indicates that the GPI understand the teaching and facilitating duty scope, especially in the class management aspect. According to Mohd Hasani and Mohamad Johdi (2009), the teacher with an excellent personality is a teacher that able to manage the classroom in order to create an effective teaching and learning atmosphere.

Level of Personality and Self-Efficacy Islamic Education Teacher Analysis

Table 6 indicates the personality and self-efficacy GPI level are in the medium-high level, which are personality level $(M=3.68, S D=0.43)$ and self-efficacy $(M=3.87, S D=0.23)$.

Table 6: Mean Value and Standard Deviation for the Personality and Self-Efficacy of GPI

\begin{tabular}{cccc}
\hline Variable & Mean & Standard Deviation & Level \\
\hline Personality & 3.68 & 0.43 & Medium-High \\
Self-Efficacy & 3.87 & 0.23 & Medium-High \\
\hline
\end{tabular}

Referring to Table 6, the result of self-efficacy level mean value is higher than GPI's personality level. Supported by the research of Noornajihan and Ab. Halim (2013) that found the level of self-efficacy of GPI is very high. According to Noornajihan and Ab. Halim (2012), teachers are the catalysing factor towards the country education transformation in producing a high cognitive competency, steadfast to the religious teachings and practising the good values in their life. Therefore, a high self-efficacy teacher is important in actualising the desire of the Malaysian Ministry of Education.

\section{The Analysis of Relationship between Personality Trait and Self-Efficacy of Islamic Education} Teacher

Table 7 shows the analysis of Pearson $(r)$ correlation test result between the relationship of personality trait and self-efficacy of Islamic education teacher. The result of analysis found that $(r)$ value $=\left(\right.$ Conscientiousness $r=0.605^{* *}$, Openness $r=0.616^{* *}$ dan Agreeableness $\left.r=0.364^{*}\right)$. Therefore, the result shows that there is a significant relationship between three personality dimensions and self-efficacy of GPI. (R) value shows that the degree of strength for Conscientiousness dan Openness dimension is medium. Meanwhile, Agreeableness dimension is weak. However, (Neuroticism $r=-$ 0.171 ) and (Extraversion $r=0.068$ ) dimensions shows that there is no significant relationship. 
INTERNATIONAL JOURNAL OF ACADEMIC RESEARCH IN BUSINESS AND SOCIAL SCIENCES Vol. 8, No. 11, Nov, 2018, E-ISSN: 2222-6990 @ 2018 HRMARS

Table 7: Relationship between Personality Trait and Self-Efficacy of GPI

\begin{tabular}{ccc}
\hline Personality Trait & Correlation Value $(r)$ & Significance \\
\hline Extraversion & 0.068 & 0.709 \\
Neuroticism & -0.171 & 0.342 \\
Agreeableness & $0.364^{*}$ & 0.037 \\
Openness & $0.616^{* *}$ & 0.001 \\
Conscientiousness & $0.605^{* *}$ & 0.001 \\
\hline
\end{tabular}

*. Correlation is significant at the 0.05 level (2-tailed).

**. Correlation is significant at the 0.01 level (2-tailed).

The finding of the study indicates that there is a significant relationship of Conscientiousness, Openness and Agreeableness on self-efficacy of GPI. Specifically, in the personality dimension itself, Openness shows a connection or the strongest relation to the self-efficacy. The finding of the study was seconded by the study done by Burkett (2011) that indicates there is a significant relationship of Openness and Conscientiousness and the classroom management effectiveness, which are one of the dimensions in the teacher's self-efficacy. The finding of the study also supported by Pandey and Kavitha (2015) which find out that there is a positive relationship between the extraversion, agreeableness, openness, and conscientiousness dimensions and the self-efficacy.

However, the neuroticism dimension does not show any significant relationship on the self-efficacy. This result is in line with the study of Pandey \& Kavitha (2015) and Hazalizah \& Nor Hasliza (2014) which found that there is no significant relationship between neuroticism and self-efficacy.

\section{CONCLUSION}

This research was conducted to identify the relationship of personality on self-efficacy of GPI in three Terengganu districts which are Besut, Setiu and Kuala Nerus. Therefore, the finding of the study can only be used in generalising the GPI in the districts related to the current study at the time when the data was collected. The result of the study found that there is three personality dimension that affects the self-efficacy of a teacher which are Conscientiousness, Openness and Agreeableness. While Pearson correlation analysis shows that there is a significant relationship between personality and self-efficacy of GPI. The Openness dimension dominates the relationship on self-efficacy compared to other personality dimensions. The characteristics of Openness teacher such as full of imagination and artistic give an advantage to a teacher in multi-various the teaching strategy during the teaching process and facilitating, to the extent that can attract student attention to study. Therefore, findings of the study prove that personality is among the vital factors in increasing self-efficacy of GPI. Hopefully, the information obtained from the current study can be used as a guide to the Malaysian Ministry of Education in general and to the school management in specific in framing the suitable programs that could increase the teaching professionalism such as teacher attitude development and personality program. The study also suggests a more specific research in order to increase teacher self-efficacy by addressing others variables such as school climate, pedagogy skill, self-appreciation and interpersonal skill. 
INTERNATIONAL JOURNAL OF ACADEMIC RESEARCH IN BUSINESS AND SOCIAL SCIENCES

Vol. 8, No. 11, Nov, 2018, E-ISSN: 2222-6990 @ 2018 HRMARS

\section{REFERENCES}

Bandura, A. (1982). Self-Efficacy Mechanism in Human Agency. American Psychologist 37 (2), p. 122-147

Barrick M.R \& Mount M.K (1991). The Big Five Personality Dimensions in Job Performance: A metaanalysis. Personnel Psychology, 44, 1-26

Burket, M. C. (2011). Relationship among teachers' personality, leadership style, and efficacy of classroom management. PhD Dissertation. The University of Southern Mississippi, Mississippi.

Costa. P.T.J. \& McCrae. R.R (1992). Revised NEO Personality Inventory (NEO-P-IR) and NEO Five-Factor Inventory (NEOFFI) Professional manual. Odessa, Florida: Psychological Assessment Resources, Inc.

Dibapile, W. T. S. (2012). A Review of Literature on Teacher Efficacy and Classroom Management. Journal of College Teaching \& Learning, 9(2), 79-92. Retrieved from http://search.ebscohost.com/login.aspx?direct=true\&db=eric\&AN=EJ986821\&lang=de\&site= ehost-live\%0Ahttp://journals.cluteonline.com/index.php/TLC/article/view/6902

Fatimahwati, H., \& Ling, S.C. (2016). Hubungan antara determinasi kendiri, personaliti big five dengan motivasi pencapaian dan pencapaian akademik. Jurnal Psikologi Malaysia 30(2): 114126 ISSN-2289-8174 114.

Feshbach. S, Weiner. B \& Bohart. A. (1996). Personality. $4^{\text {th }}$ Ed. Toronto: D.C. Health and Company.

Gordana, D., Snezana, S., Mila, D. (2013). Basic Personality dimensions and teachers' efficacy. Procedia Social and Behavioral Science 112 92014) 593-602

Hamzah, H. (2011). Hubungan antara personaliti dan kepengikutan dengan prestasi kerja dalam kalangan guru sekolah rendah di Wilayah Persekutuan Kuala Lumpur. PhD Dissertation. Tanjung Malim, Universiti Pendidikan Sultan Idris.

Hamzah, H. (2014). Pengaruh Dimensi Personaliti dan Gaya Pengajaran ke Atas Efikasi Kendiri Guru Matematik Sekolah Rendah. Proceedings of the International Conference Teaching and Learning (ICTL 2014), Sultan Idris Education University, Perak, Malaysia. 26-28 Mei 2014.

Heinstrom. J. (2003). Five Personality Dimensions and Their Influence on Information Behaviour. (9) 1.http://information:net/ir/9-1/paper165.html

John, O. P. \& Srivistana, S. (1999). The Big Five Trait Taxonomy: History, Measurement, and Theoritical Perspectives. University of California. To appear in L. Pervin, and O.P. John, (Eds.), Handbook of Personaliti: Theory and Research ( $2^{\text {nd }}$ ed.). New York: Guilford Press. 
INTERNATIONAL JOURNAL OF ACADEMIC RESEARCH IN BUSINESS AND SOCIAL SCIENCES

Vol. 8, No. 11, Nov, 2018, E-ISSN: 2222-6990 (C) 2018 HRMARS

Pandey N., S., \& Kavitha, M. (2015). Relationship between Teachers' Personaliti Traits and Self Efficacy: An Empirical Analysis of School Teachers in Karaikal Region (Puducherry). Pacific Business Review International Volume 8, Issue 3.

Pervin, L.A. \& Cervone, D. (2010). Personaliti: Theory and research. (11th ed.). International Student Version. New Jersey, USA: John Wiley \& Sons, Inc.

Ryckman, R. M. (2013). Theories of Personality. (10th ed.). Belmont, California: Wadsworth Cengage Learning.

Schultz, D.P \& Schultz, S.E. (2009). Theories of personality. (9th.ed.). Belmont, California: Wadsworth Cengage Learning.

Tschannen-Moran, M., \& Hoy, W. A. (2001). Teacher Efficacy: Capturing an elusive construct. Teaching and Teacher Education, 17, 783-805. https://doi.org/10.1016/S0742-051X(01)00036$\underline{1}$

VandenBos, G. R. (Ed). (2007). APA dictionary of psychology. Washington, USA: American Psychological Association. 